\title{
Scale-up of cell culture bioreactors using biomechatronic design
}

Carl-Fredrik Mandenius and Mats Björkman

\section{Linköping University Post Print}

N.B.: When citing this work, cite the original article.

This is the authors' version of the published article:

Carl-Fredrik Mandenius and Mats Björkman, Scale-up of cell culture bioreactors using biomechatronic design, 2012, Biotechnology Journal, (7), 8, 1026-1039.

http://dx.doi.org/10.1002/biot.201100463

Copyright: Wiley-VCH Verlag Berlin http://www.wiley-vch.de/publish/en/

Postprint available at: Linköping University Electronic Press http://urn.kb.se/resolve?urn=urn:nbn:se:liu:diva-84358 
Scale-up of cell culture bioreactors using biomechatronic design

Carl-Fredrik Mandenius ${ }^{1}$ and Mats Björkman ${ }^{2}$

'Division of Biotechnology/IFM, ${ }^{2}$ Division of Assembly Technology/IEI, Linköping University, 58183 Linköping Sweden

Correspondence: Prof. Carl-Fredrik Mandenius, Division of Biotechnology/IFM, Linköping University, 58183 Linköping Sweden

E-mail: $\underline{\text { ffm@ifm.liu.se }}$

Abbreviations: GMP, good manufacturing practice; PAT, process analytical technology; QbD, quality by design;; TrP, transformation process; 


\begin{abstract}
An alternative approach for scale-up of cell culture bioreactors based on biomechatronic design methodology is suggested.

The approach differs from traditional biochemical engineering methodology by applying a sequential design procedure where the needs of the users and alternative design solutions based on the biological and technical functions of the scaled-up bioreactor are derived in functional maps, concept generation charts and scoring and interaction matrices. Basic reactor engineering properties, such mass and heat transfer and kinetics are integrated in the procedure. Examples are provided from production of monoclonal antibody and recombinant protein.
\end{abstract}

Keywords: Scaling-up; Biomechatronic design; Bioreactor engineering; Mammalian cell culture; Systematic design 


\section{Introduction}

Efficient scale-up of bioreactors for production of mammalian cells is a great challenge in bioengineering [1-3]. Increasing industrial use of mammalian cell cultures for a variety of purposes, such as production of biopharmaceuticals [3-5] and expansion and differentiation of embryonic stems [6-9], emphasizes the need of reliable and successful scale-up methodology.

Mammalian cell culture systems have a number of characteristic features that are important to consider in scaling-up [2, 10-12]. Cell culture protocols use expensive and sensitive culture media whereas volumetric product titres are modest. Mammalian cell cultures are generally more vulnerable to large scale effects than microbial cultures. Typical scaling-up issues, such as homogeneity of the reaction system with the cells, and shear stress effects exerted on the cells due to agitation and bursting bubbles, have to be considered in the light of the sensitivity of the cell membranes of the mammalian cells. Other important effects are gradients of $\mathrm{pH}$ and $\mathrm{CO}_{2}$ which have to be addressed in relation to productivity and yields for the cultures.

The design and construction of cell culture bioreactors depend on the skill of approaching these scale-up issues. So far, cell culture reactor design has to a large extent relied on classical chemical engineering approaches [10]. Mostly, key components in the design, such as impellers, baffles, spargers and heat

exchangers have been designed and dimensioned based on experiences and descriptions of the properties of these design elements. Well established design methods in chemical engineering, for example using dimensionless numbers in combination with heat and mass transfer equations have been of great value but have also been strongly dependent on reliable measurement methods [13].

When designing and developing products in the field of mechanical engineering, the design approach is largely different. Mostly, the design methodology is founded on genuine conceptual and systematic thinking. The principles of the systematic design for mechanical products have thoroughly been described in the engineering literature [14-17]. Application of the systematic design is usually 
extended to include mechatronic products, such as vehicles, tools, industrial robots and machines. Most systematic design approaches in mechanical engineering have in common that a holistic methodology is applied where the functionality of the intended product is directing the generation of design alternatives.

The mechanical engineering design methodology has recently been applied to biotechnology products $[18,19]$. The term biomechatronic design has been coined to highlight that the biotechnology products merge biological, mechanical and electric/electronic systems into one product where the complexity is considerable compared to other engineered products.

Biomechatronic design has recently been described for a variety of such complex biotechnology products [18-22]. Examples include bioreactors, biosensors, chromatographic protein purification systems [19, 20], stem cell manufacturing plants and quality control for bio-production using to Process Analytical Technology (PAT) and Quality-by-Design methods [21, 22].

In this article we discussed how the biomechatronic design methodology can be applied to critical design issues at the scale-up of bioreactors for cell cultures. In particular, cell cultures for recombinant protein production are considered, but the design methodology is general and can be applied to any bioproduct to be scaled-up in a bioreactor system. 


\section{Biomechatronic design methodology}

As mentioned above, the current methodologies for engineering design are mostly associated with development of mechanical or mechatronic products [15, 17]. These well established methodologies can, however, be adapted for biotechnology product development by introducing an extended reasoning for the biological parts of the products.

Biomechatronic design methodology provides this opportunity [18, 19]. The methodology is mainly based on two previously well known methodologies, the Ulrich-Eppinger [17] and the Hubka-Eder [23-25] engineering design approaches. In the Ulrich-Eppinger approach the starting point is the identification of the critical needs and requirements on the product to be design from the user angle. These requirements are then specified in detail and target values are allotted. With these boundary conditions, a multitude of conceptual design solutions are generated. The design solutions are evaluated and scored, and a few selected solutions are further developed and systematically tested and prototyped. The user requirements are identifiable for most biotechnological machines or devices and can be described with metrics related to purity, bioactivity, yield, and analytical sensitivity, for example.

The other design methodology for generating and analyzing design solutions applied in the biomechatronic design approach is based on the Hubka-Eder theory for conceptual design [23]. The methodology relies on a detailed description of the transformation that shall be carried out by the designed machine, where inputs of materials, energy and signals are processed and where outputs are created (see Fig. 1). The phases in the transformation are identified and described and the entire transformation process is divided into sequential or parallel steps which all contribute to its realization. To accomplish the transformation, different systems are required which can be categorized either as biological, technical, human, information or management \& goal systems. These systems have in common that they all cause effects on the transformation process. For biotechnology products the biological systems have key roles in the 
transformation, but also their interactions with the other systems are crucial for efficient operation $[19,20]$.

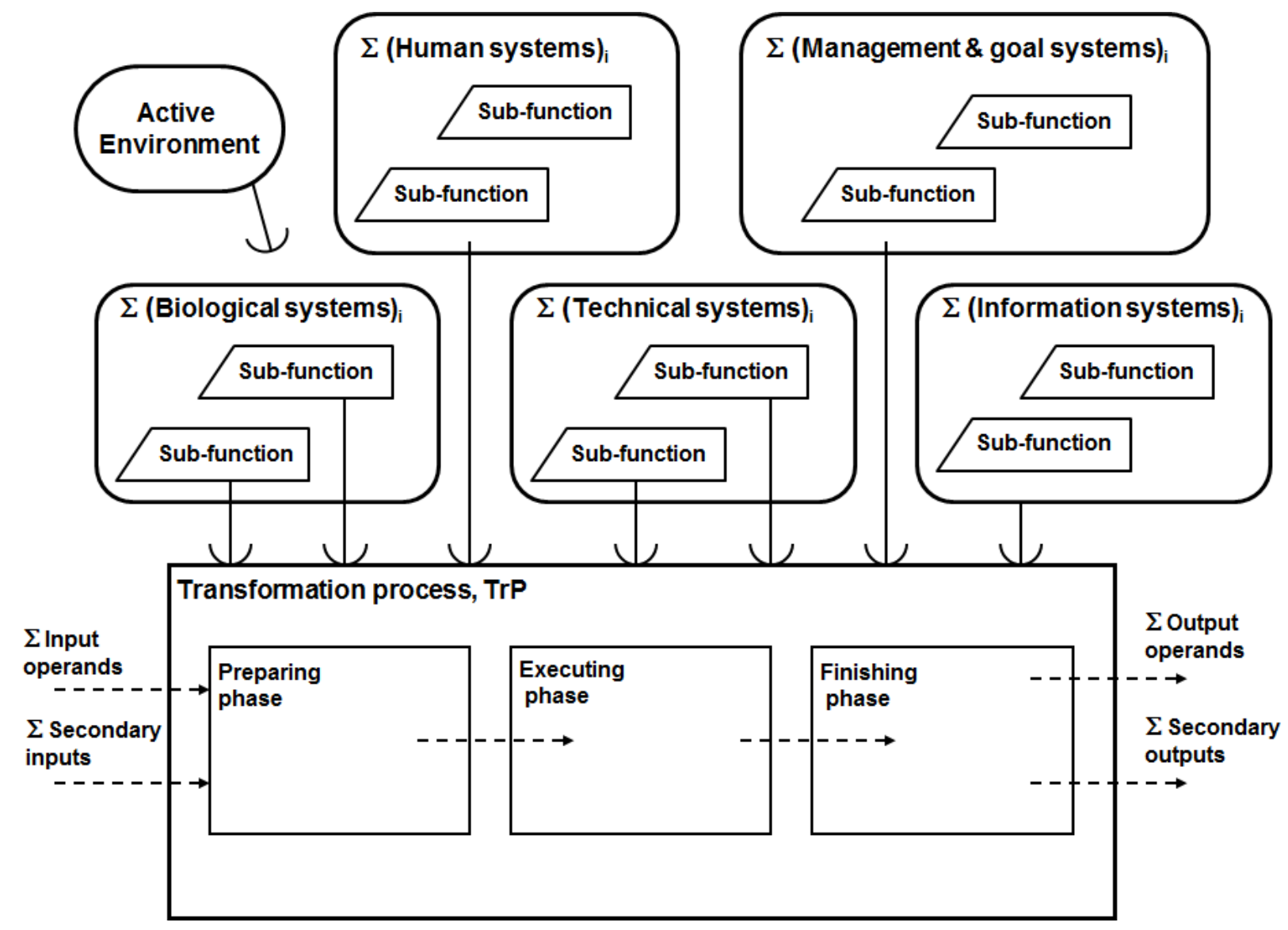

\section{Figure 1}

A general overview Hubka-Eder map that is applicable to any engineering process or product to be systematically designed for subsequent manufacture or to be used for performing a technical mission.

The methodologies described above can be applied sequentially as outlined in Figure 2. The sequential steps can be adapted to any biotechnology product such as a bioreactor, a whole bioprocess, recovery unit operations or an analytical instrumentation. Thus, it could be a whole continuous bioprocess as well as a single-unit device or an on-line process sensor. 
In the scheme of figure 2, the requirements or needs of the user on the machine are first identified. A number of attributes are listed to a level of detail that is meaningful for the accomplishment of the design work.

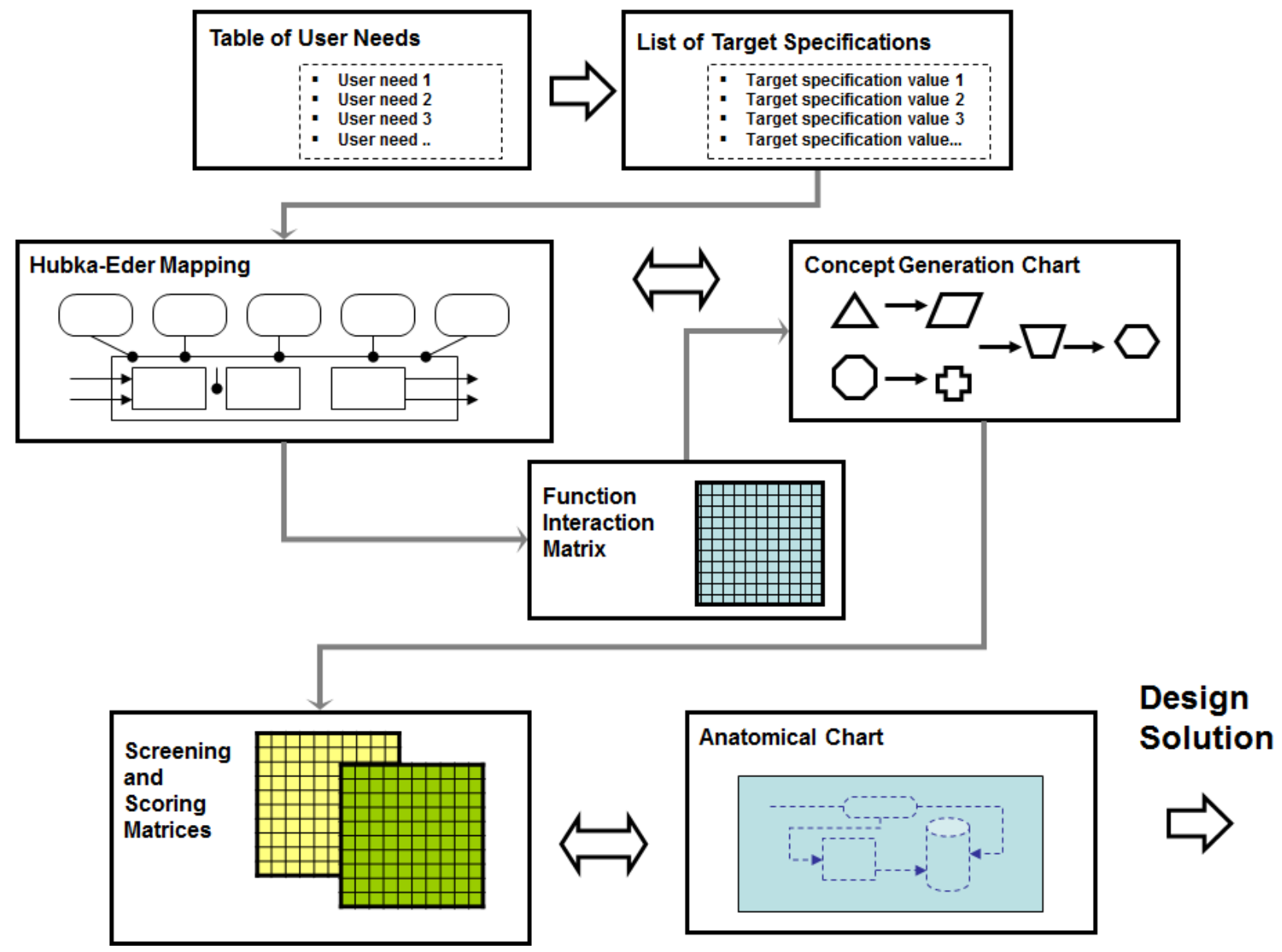

\section{Figure 2}

The main stages of the biomechatronic design methodology: identification of user needs and target specifications for the product to be designed, depiction of a Hubka-Eder map and generation of concept alternatives, screening and scoring of the design concept alternatives, and, finally, adapting the top-ranked concepts to an anatomical configuration.

Second, the attributes are converted to a new list that specifies target values. These targets can either be quantifiable metrics or qualitative properties that 
should be fulfilled by the product. The target can be a specific number, or it can be a range which allows proper function of the product.

Third, based on the target specifications a Hubka-Eder map is worked out. The transformation process in the Hubka-Eder map can easily be projected and adapted to transformations caused by biomolecules, enzyme or cells. For example, a laboratory bioreactor can be represented in the Hubka-Eder map with its transformation of nutrients and media into biological products. The cell culture inoculum becomes the active biological system and the reactor vessel with pumps and impeller are the actual technical systems. Electrodes and flow meters form the information systems, the control software with the operator interface, the management systems and the operators the human systems (cf. Fig. 1).

Subsequently, or in parallel with the Hubka-Eder map, a basic conceptual design structure is generated where the functions necessary for the realization of the product are clearly envisaged. From this conceptual structure, different design solutions are generated in a Concept Generation Chart (Fig. 2).

The functional analysis in the Hubka-Eder map and concept generation chart are supported by an evaluation of the interactions of the functions and sub-functions of the systems and the steps in the transformation process. This is done in a Functions Interaction Matrix (FIM). In the matrix the strengths and impacts of the interactions are ranked and from that, critical parts of the design solutions are identified. This may lead to a redesign or adaption, or it may lead to abandoning a certain design concept. The concept solutions are compared by systematic screening and scoring of the attributes of the target specifications.

Finally the design concepts selected in the screening are analyzed with real construction components, so called anatomical objects. These are configured in an anatomical chart. Several anatomical charts are considered and screened and ranked towards the target specifications. The result of the iterative procedure will be a refined design solution (Fig. 2).

Using this systematic structuring of the parts and functions of the design, various concepts are built and analyzed. Any biotechnology machine or apparatus or 
system can be designed with the support of the methodology, either it is a largescale process, a protein purification system, a biosensor or microarray instrument [18-20]. 


\section{Systematic design of scale-up of cell culture bioreactors}

Applying the biomechatronic methodology in scaling-up of mammalian cell culture bioreactors may efficiently support the development work. In particular, it can facilitate a more systematic adaption of a culture method from the research laboratory to large scale manufacturing.

The first step of the biomechatronic methodology is to define the needs on the scale-up of the bioreactor for the particular cell line and the product to be expressed, e.g. a recombinant protein or a monoclonal antibody (cf. Fig. 2).

Table 1 lists common needs and expectations related to scale-up of cell culture bioreactors that industry-oriented bioengineers frequently mention: a homogeneous culture volume without dissolved oxygen and $\mathrm{pH}$ gradients, efficient heat transfer to all volume elements of the culture, and an agitation procedure of the scaled-up bioreactor that do not change the cells' capacity to grow and express protein products $(2,26-28]$.

Several of the needs in Table 1 reflect the overall goal for the scale-up: to maintain the same volumetric productivity of the culture as at the laboratory scale. Already here it is wise to highlight physical and biological processes that will facilitate the identification of the TrP in the Hubka-Eder map.

In Table 2 the user needs in Table 1 are specified as quantitative or semiquantitative target metrics. The biochemical engineering literature provides an ample supply of data that can be used and adopted for defining appropriate targets (see e.g. [29]). For example, the $k_{L} a$ in a hybridoma culture for monoclonal antibody production should typically be in the order of $1-10 \mathrm{~h}^{-1}$ [30]. Other target values may be acquired through internal or external expert consultations or by theoretical calculations. Economically related targets could be included as well, such as cost for the scale-up development, capital costs and operational costs. The examples given in Table 2 illuminate how need attributes are transformed to specifications where preliminary target values are set based on typical values from reported cell culture production systems. 
The needs and target specifications provide a starting point for the Hubka-Eder mapping. In Figure 3 an overview map of the cell culture bioreactor to be scaledup is shown, including the transformation process and the systems that take part in the transformation of cells, nutrients and energy to new cells and products (e.g. a genetically engineered or transformed cell line or isolate or a recombinant protein as shown in the figure).

A
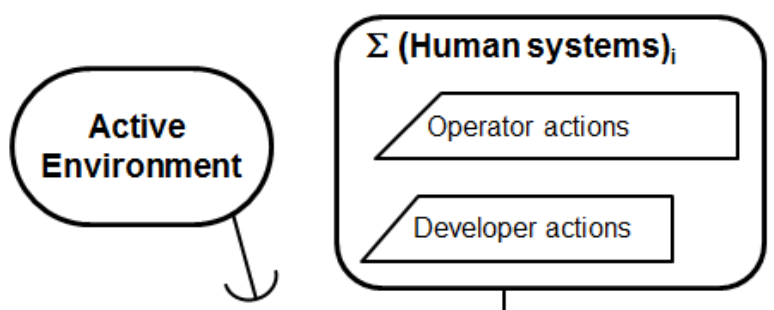

$\Sigma$ (Management \& goal systems)
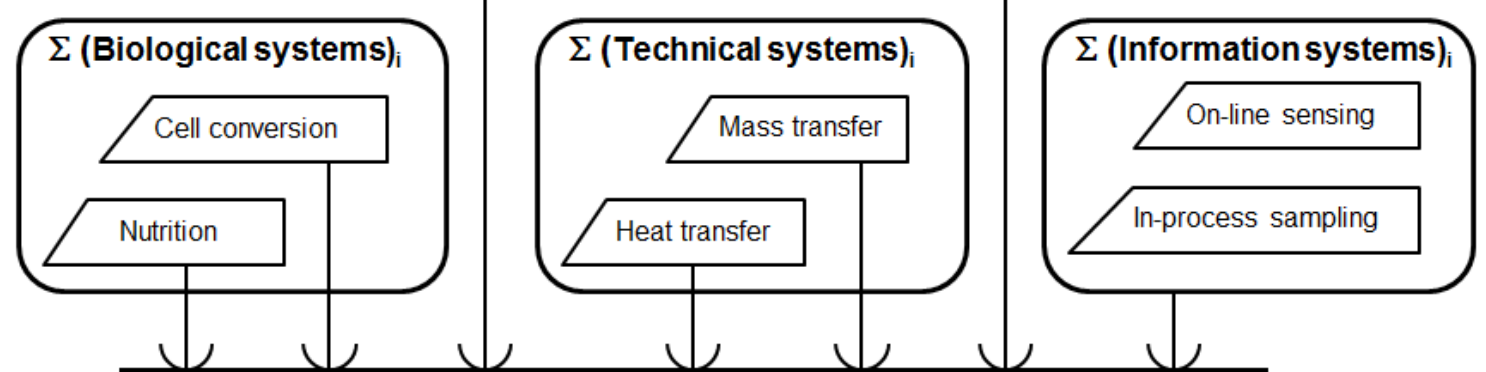
Transformation process, TrP

$\Sigma$ Operands in:

Cells

Nutrients

Air
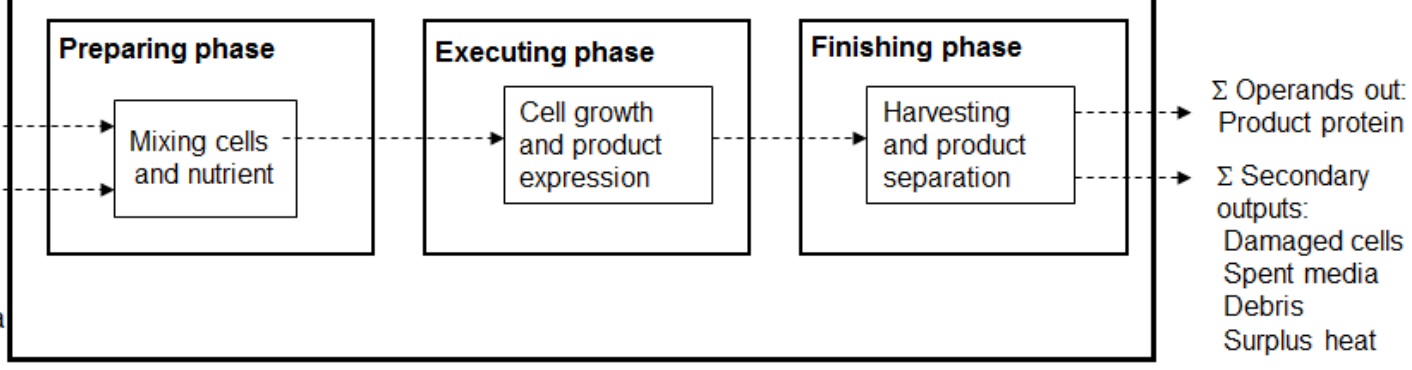

$\Sigma$ Secondary

inputs:

Energy

Cooling media

Acid/base 

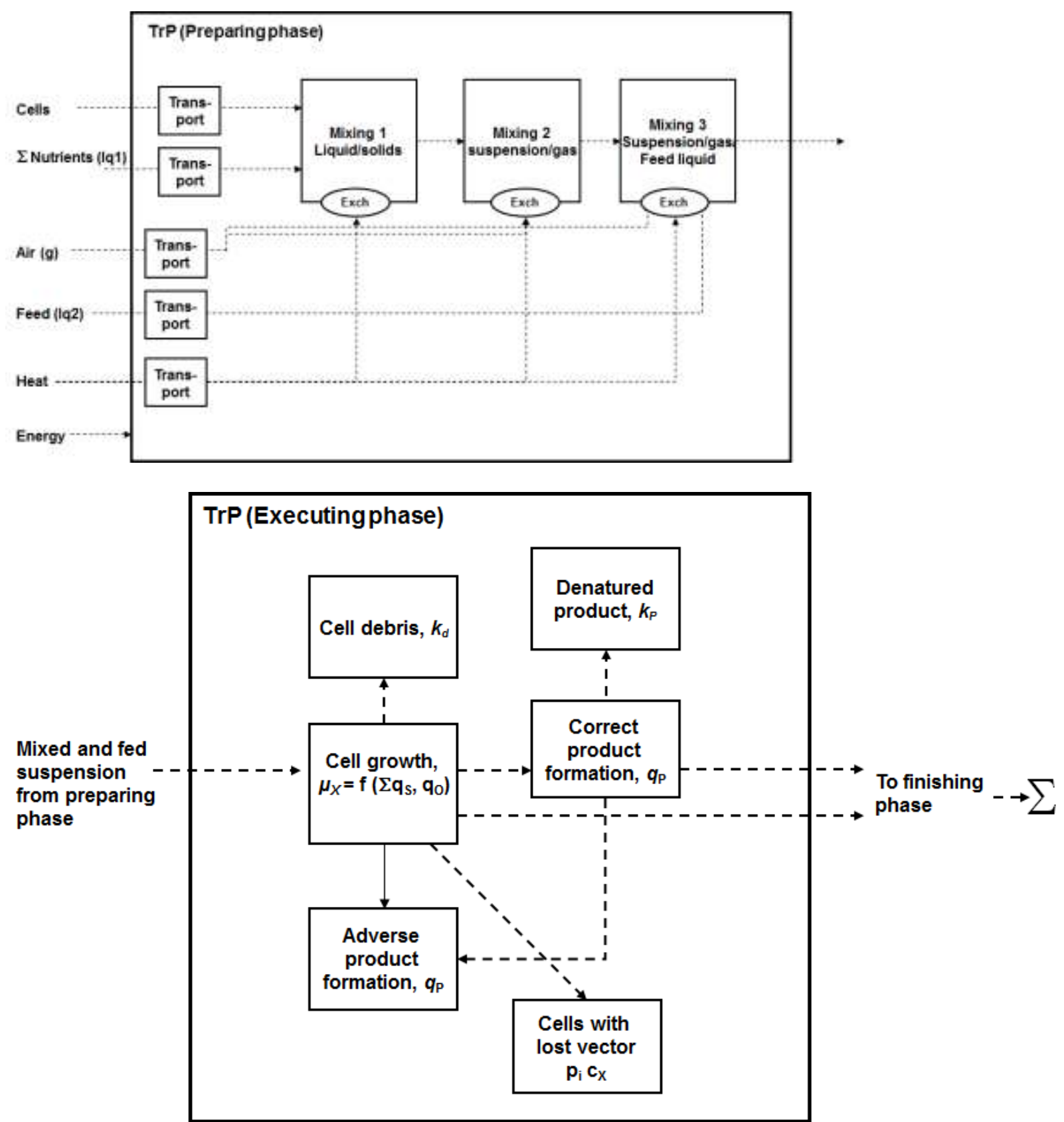

\section{Figure 3}

An overview Hubka-Eder map of the cell culture bioreactor to be scaled-up showing the transformation process in the bioreactor and the functions and subfunctions of the systems involved for carrying out the transformation process. 
The transformation process is, as described above in the methodology section, divided into preparing, executing and finishing phases for the transformation in the cell culture bioreactor.

In the preparing phase, mammalian cells, nutrient media and air are mixed to a homogeneous fluid (Fig. 4A). This is considered as a preparing transformation for the subsequent executing phase. Note that also the addition of feed media for fed-batch operation of the bioreactor is a preparing transformation. This is because it goes through the same transformation as the previous mixing steps although it occurs subsequently and continuously. If also another component is added during cellular growth, e.g. an inducer for initiating the expression, this would pass the preparing phase as well.

In the executing phase, the biological transformation, i.e. the growth of cells and their conversion of nutrients and their expression of a protein product, occurs. Thus, in a cell culture process for production of a recombinant the transformations occurring in the executive phase include the growth of the cells, the export of the recombinant protein from the cells and the formation of primary metabolites, e.g. lactate and ammonia, and their excretion to the culture media. The Figure 4B also includes a box for expressed proteins that are denatured and another box for proteins that are adversely transformed (e.g. as truncated forms) as well as cells that transform into non-productive cells due to loss of vector. Note that these transformation events are not necessarily separated physically as the map implies, but are processed in the same cellular space.

In the finishing phase harvest of the cells and the product molecules is carried out. This requires mass transport for separating and concentrating cells and proteins to purities and concentrations according to in the target specifications. Expected yield factors of products as targeted are considered as well.

The TrP part of the Hubka-Eder map is surrounded by the functional systems that shall accomplish the transformation. The biological systems, $\Sigma B i o S$ (Fig. $5 \mathrm{~A}$ ), are divided into six subfunctions. These are (1) the capacity of the cells to grow, (2) the transfer of the target gene(s), (3) the capacity of the transfected cells to 
A

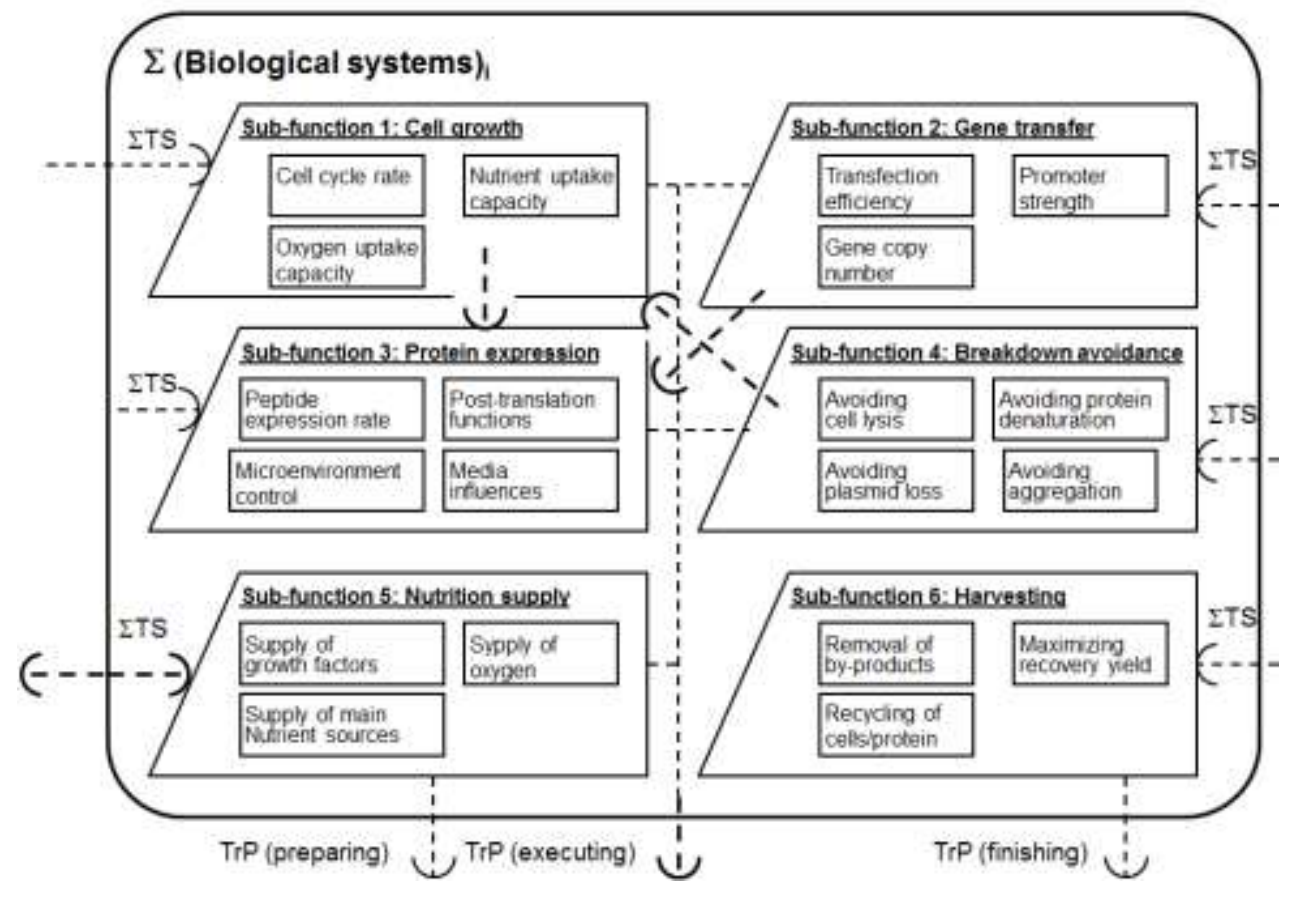

B

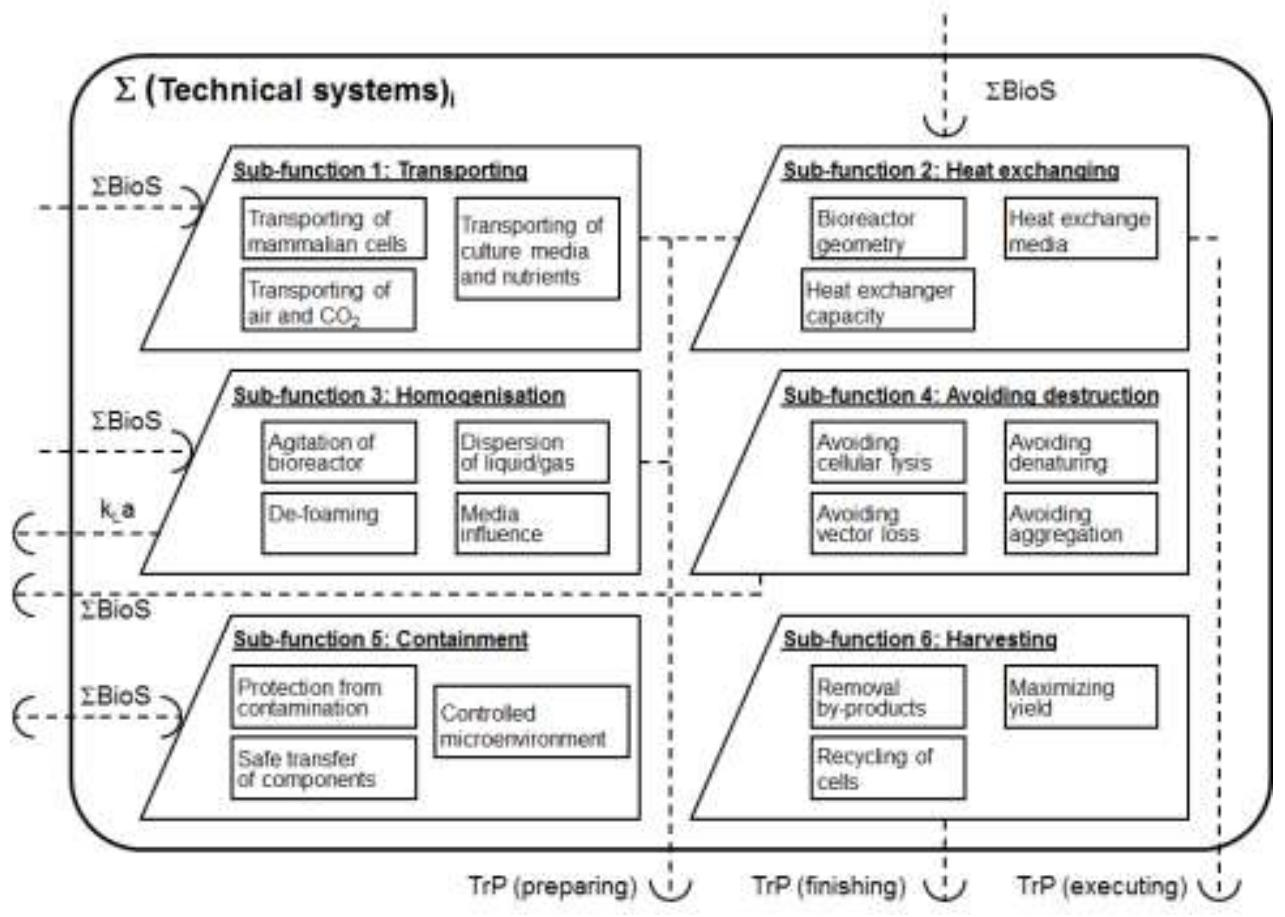

Figure 4

A zoom-in Hubka-Eder map of the preparing phase $(A)$ and the executing phase of the transformation process of the cell culture bioreactor $(B)$. The figure refers to a typical cell culture expressing a recombinant protein. 
A

\begin{tabular}{|c|c|c|c|c|c|}
\hline \multirow{2}{*}{\multicolumn{2}{|c|}{$\begin{array}{l}\text { Functions } \\
\qquad \begin{array}{l}\text { Sub- } \\
\text { functions }\end{array}\end{array}$}} & EBios & $\Sigma T S$ & Eis & LM\&GS \\
\hline & & \begin{tabular}{|lll}
$5 F 1$ & $5 F 2$ & $5 F 3$ \\
\end{tabular} & \begin{tabular}{|lll}
$5 \times 1$ & $5 \times 2$ & 583 \\
\end{tabular} & \begin{tabular}{|lll}
$5 F 1$ & $5 F 2$ \\
\end{tabular} & \begin{tabular}{|lll}
551 & 552 & $5 F 3$ \\
\end{tabular} \\
\hline$\frac{\text { 口 }}{\text { 离 }}$ & $\frac{\mathbb{4}}{5}$ & $\begin{array}{l}\text { inceractions - } \\
\text { behween } \\
\text { bfological } \\
\text { subfunctions }\end{array}$ & $\begin{array}{l}\text { infaractions } \\
\text { exerted- by } \\
\text { bialogical } \\
\text { subfunctions } \\
\text { an iecthical } \\
\text { subfunctions }\end{array}$ & $\begin{array}{l}\text { Interactions } \\
\text { exerted by } \\
\text { blological } \\
\text { subfunctions } \\
\text { an information } \\
\text { subfunctions }\end{array}$ & $\begin{array}{c}\text { Intoractions } \\
\text { everted by } \\
\text { blological } \\
\text { subfunctions } \\
\text { on mansagement } \\
\text { subfunctions }\end{array}$ \\
\hline 兽 & $\frac{5}{5}$ & $\begin{array}{l}\text { Intaractions } \\
\text { exerted by } \\
\text { technical } \\
\text { subfunctions } \\
\text { on bilatogical } \\
\text { subfunctions }\end{array}$ & $\begin{array}{l}\text { Interactions } \\
\text { benween } \\
\text { nechnical } \\
\text { subblunctions }\end{array}$ & $\begin{array}{l}\text { Interactions } \\
\text { ererted by } \\
\text { technical } \\
\text { subfunctions } \\
\text { on information } \\
\text { subfunctions }\end{array}$ & $\begin{array}{c}\text { interactlons } \\
\text { exarted by } \\
\text { technical } \\
\text { subtunctions } \\
\text { on managenent } \\
\text { subfunctions }\end{array}$ \\
\hline$\frac{n}{\Lambda}$ & $\frac{5}{5}$ & $\begin{array}{l}\text { intoractions } \\
\text { excomed by } \\
\text { information } \\
\text { subfunctions } \\
\text { on biological } \\
\text { subfunctions }\end{array}$ & $\begin{array}{l}\text { intaractions } \\
\text { everned-by } \\
\text { information } \\
\text { subfunctions } \\
\text { an recthical } \\
\text { subfunctions }\end{array}$ & $\begin{array}{l}\text { Interactions } \\
\text { between } \\
\text { information } \\
\text { subtumctions }\end{array}$ & $\begin{array}{l}\text { interactions } \\
\text { exertod ty } \\
\text { information } \\
\text { subfunctions } \\
\text { on management } \\
\text { subfunctions }\end{array}$ \\
\hline 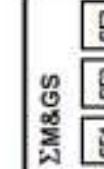 & 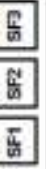 & $\begin{array}{l}\text { Intaractions } \\
\text { exerred by } \\
\text { manogement } \\
\text { subfunctions } \\
\text { on biological } \\
\text { subfunctions }\end{array}$ & $\begin{array}{l}\text { interactions } \\
\text { averted by } \\
\text { maragement } \\
\text { subfunctions } \\
\text { an tectinical } \\
\text { subfunctions }\end{array}$ & $\begin{array}{l}\text { Interactions } \\
\text { exiarted by } \\
\text { management } \\
\text { subfunctions } \\
\text { an information } \\
\text { subfunctions }\end{array}$ & $\begin{array}{l}\text { buteractions } \\
\text { befween } \\
\text { management and } \\
\text { goal subfunctions }\end{array}$ \\
\hline
\end{tabular}

B

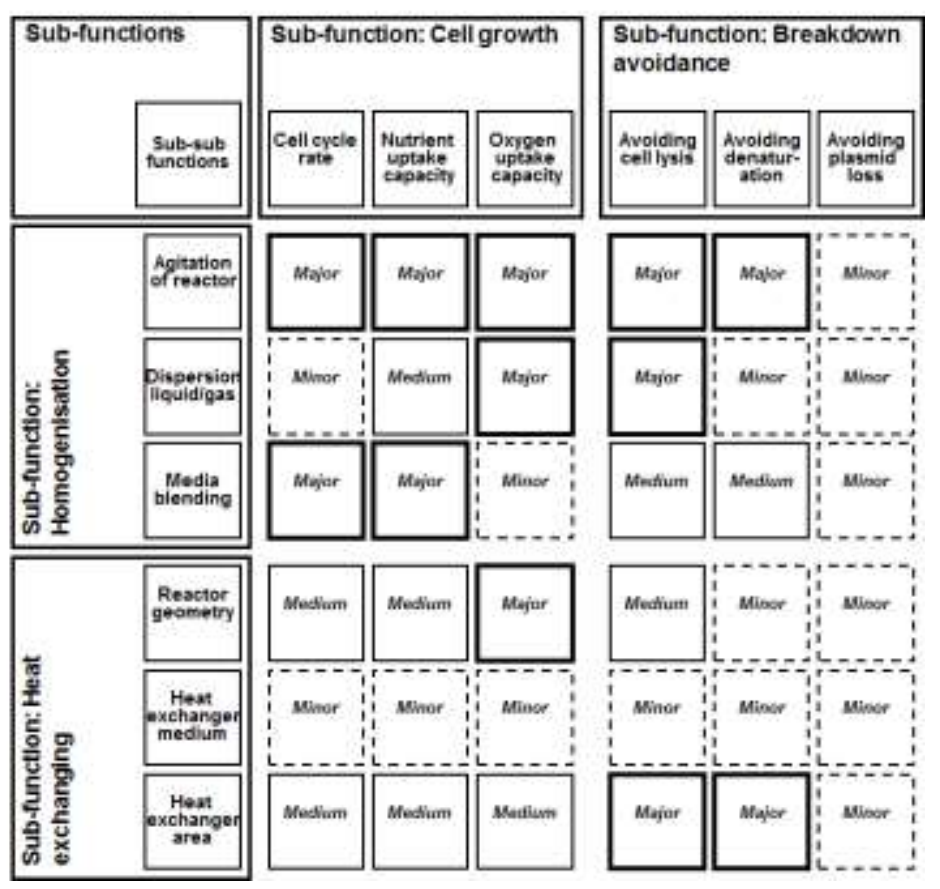

Figure 5

(A) The biological systems ( $\Sigma$ BioS) of the Hubka-Eder map for a mammalian cell process. (B) The technical systems ( $\Sigma T S$ ) of the Hubka-Eder map for a mammalian cell process. 
express the transferred gene as a protein, (4) the breakdown of cells and target (here, described as avoidance of these functions), (5) the supply of nutrients, and (6) the harvesting of the cells and target proteins. In a cell culture producing a recombinant protein with e.g. a $\mathrm{CHO}$ or HEK cell line, growth may occur in a suspension culture; the target gene copies are introduced in the cells by transfection in a selected vector; the target protein is expressed and glycosylated. Then, it may undergo breakdown by proteolytic activity. Nutrient supply components play an active role in stimulating the growth and the expression. The harvesting of the protein is influenced by the culture media composition and cellular by-products and recycling of the culture.

The $\Sigma$ BioS in Figure 5A show biological functions that to large extent can be described by established kinetic rate equations for the biological components involved [1,3], e.g. the uptake of nutrient substrates:

$$
r_{S i}=q_{\mathrm{Si}} X=q_{X} Y_{S i / X} X
$$

The uptake of oxygen:

$r_{O}=O U R=q_{o} X=k_{L} a\left(C_{L}^{*}-C_{L}\right) X$

and the formation of the product according to the the Luedeking-Piret equation:

$$
r_{P}=q_{P} X=\alpha q_{X}+\beta
$$

Alternatively, the kinetics can be modelled by more elaborate kinetics [31, 32]. Examples of other critical rates are the lysis of cells, $k_{\mathrm{d}(\mathrm{cells})}$, and the denaturation of proteins, $k_{\mathrm{d}(\text { protein). }}$. Decisive interactions between the functions are indicated in Figure 5A; these shall be further analyzed (see below).

The technical systems, $\Sigma T S$, are analysed from the functionality angle as well. Again, the physical components or devices are not considered at this stage but the subfunctions they should perform. The main functions and subfunctions are, as also evident in the phases of the $\operatorname{Tr} P$, transportation and transfer of media, agitation, heat transfer, containment of the system, harvesting of the products, decontamination, and the formation of cells and proteins. In Figure 5B six 
subfunctions are included: transportation, heat exchanging, homogenisation, avoidance of destruction of cells, containment of the biological systems, and harvesting of product. Of particular interest are those subfunctions that can be associated with established reactor engineering equations [2]. This includes e.g., the power input [33]:

$$
P=P_{O} \rho N^{3} D^{5}
$$

where the density $(\rho)$ is a direct result of the culture media composition, i.e. an interactive effect of a $\Sigma$ BioS subfunction, and the impeller speed $(M)$ and diameter $(D)$ of the chosen impeller geometry, i.e., interactions with other subfunctions of the $\Sigma T S$.

It also includes the oxygen mass transfer to the cells which depends of the $k \mathrm{~L} a$ coefficient [34]:

$k_{L} a=A\left(\bar{\varepsilon}_{T}\right)_{g}^{\alpha}\left(v_{S}\right)^{\beta}$

where $\left(\bar{\varepsilon}_{T}\right)_{g}=\left(\bar{\varepsilon}_{T}\right)_{S}+\left(\bar{\varepsilon}_{T}\right)_{I g}$, which represents the mean dissipation energy rate achieved by the air sparging of the bioreactor, $\left(\varepsilon_{\top}\right)_{\mathrm{S}}$, and the impeller capacity, $\left(\varepsilon_{\top}\right)_{\lg }$. These are rates that directly interact with the subfunction of homogenisation.

The oxygen mass transfer coefficient depends also on solubility of the oxygen in the culture medium, $C_{\mathrm{AL}}{ }^{*}$, according to:

$$
k_{L} a=\frac{N_{A}}{C_{A L}^{*}-C_{A L}}
$$

where $N_{A}$ is molecules transferred and $C_{A L}$ the dissolved oxygen in the liquid [33]. Temperature and medium activity exert effect of the solubility. Thus, these are other interactive dependencies with other subfunctions of the technical systems which influence the design (cf. arrows in Fig. 5B).

Other subfunctions of the technical systems relate to the metabolic heat transfer from the culture, as can be assessed from: 


$$
Q_{H} \approx 5 \times 10^{5} \text { OUR }
$$

where the oxygen uptake rate is an effect of the respiration capacity of the BioS [35]. The mixing time to homogeneity can be assessed from:

$$
\Theta_{m} \propto(H / D)^{2.43}
$$

where the geometry of the containment (as aspect ratio $H / D$ ) affects the mixing time $\left(\Theta_{m}\right)[2]$.

The other systems shown in the overview Hubka-Eder map (Fig. 3) - the information systems $(\Sigma / S)$, the human systems $(\Sigma H u S)$ and the management and goal systems $(\Sigma M \& G S)$ - are here not analysed in their details. However, they may be useful for mapping scale-up associated functions, for example, how to better control the bioreactor at a larger scale and how to carry out a scale-up protocol. Neither is the Active Environment, AEnv, discussed. This could, however, be justified if influences of a fluctuating temperature or prevalence of contaminants in the ambient air are critical. In particular, if the purpose with the design is to apply principles of QbD and PAT [21,36-38] or advanced process control [34] these parts need to be detailed at a significantly higher resolution in the design.

Of great importance is to analyse the effects imposed by and between the functions and subfunctions. The anchor arrows show critical directions and/or targets of overall functions and subfunctions. The arrows are by necessity crossing the borders of the systems' compartments and of the TrP since they execute their effects both on the transformation sub-processes per se, but also on the other functions of the systems.

The graphs in Figures 3 and 5 do not map the entire complexity of interactions in the bioreactor design. A complete mapping requires a higher resolution of the functional structure than shown in this article. However, principally the same methodology could be used to establish detailed maps through a systematic and methodical procedure (see [19]). This procedure should be iterative. By going 
back and adjusting the structure of the map, it will gradually be refined, and by that, depict the complexity of the process more precisely.

The functions and subfunctions captured in the Hubka-Eder map need further analysis. This is, as mentioned above, best done by using the functions interaction matrix (FIM) format where the effects of the interactions of the different subfunctions are assessed. Figure 6 shows two such matrices where the interactivity of the functionalities of the systems is investigated. In Figure $6 \mathrm{~A}$ an overview FIM with the main systems is shown. Note that the interactive effects have two directions in the matrix representation; the functions of the $\mathrm{Y}$-axis exert effects on $\mathrm{Y}$-axis functions or can be affected by functions on the $\mathrm{X}$-axis.

The FIM analysis needs to be carried out with higher resolution to be useful. This is done in Figure $6 \mathrm{~B}$ where the overview matrix is zoomed-in into those subfunctions that in Figure $6 \mathrm{~A}$ have strong effects. Sub-subfunctions are here included and their effects are assessed as well. If the interaction effects are considerable, these are believed to have significant impact on the scale-up.

For example, in Figure 6B the cell growth subfunction of the biological systems is divided into cell cycle rate, nutrient uptake capacity and oxygen uptake capacity. These sub-subfunctions are compared with the homogenisation subfunction of the technical systems. The homogenisation is divided into the sub-subfunctions of agitation of the bioreactor, the dispersion of liquid-gas interface and the blending of the liquid media. The strength of interactions between several of these functions are indicated as major. The agitation has major impact on the cell cycle rate, and the nutrient and on oxygen uptake capacities. In e.g. a hybridoma cell culture this is also the case for the dispersion of liquid-gas interface on oxygen uptake and blending of media on cycle rate and nutrient uptake. These major interactions have in particular influence on generation of concepts $i$ to $v i$ in Figure 7B. 
A

Basic conceptual component chart
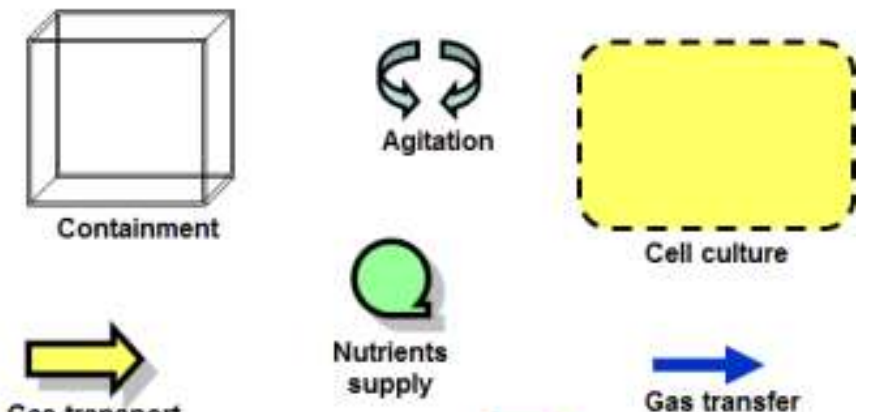

Gas transport

Gas permeable surface

B

\section{Permutation chart}

(i)

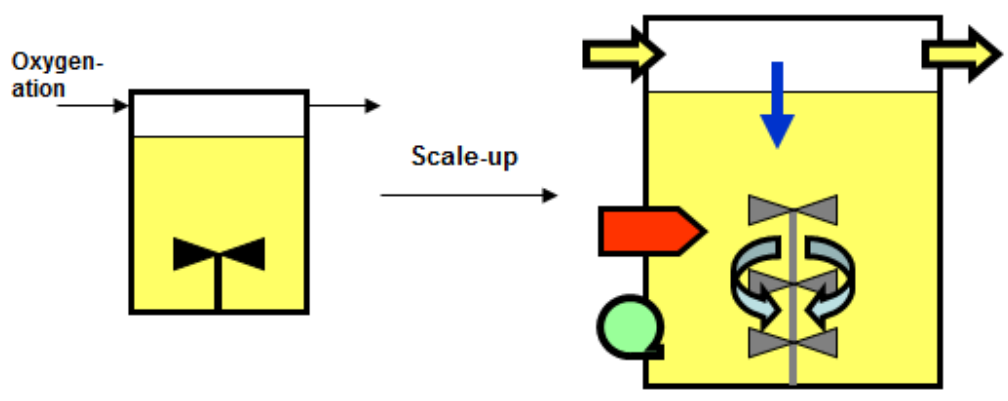

(ii)
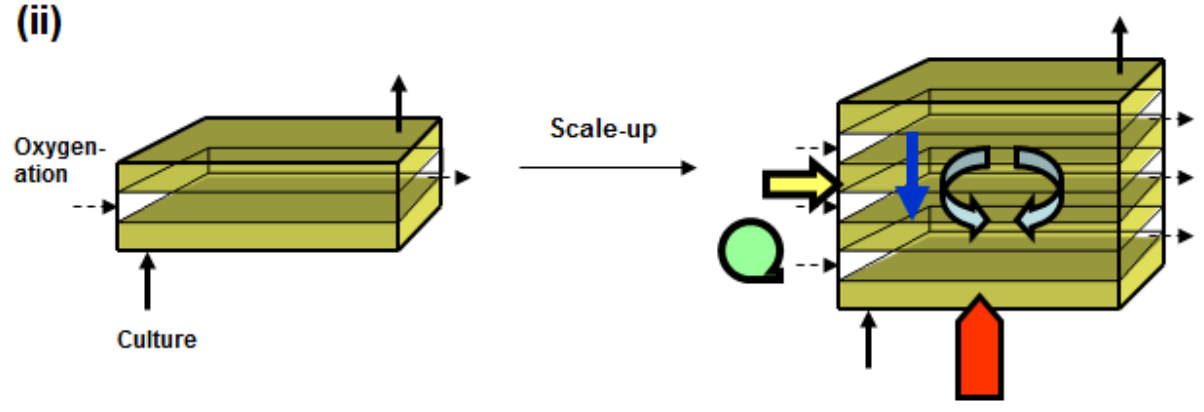

(iii)
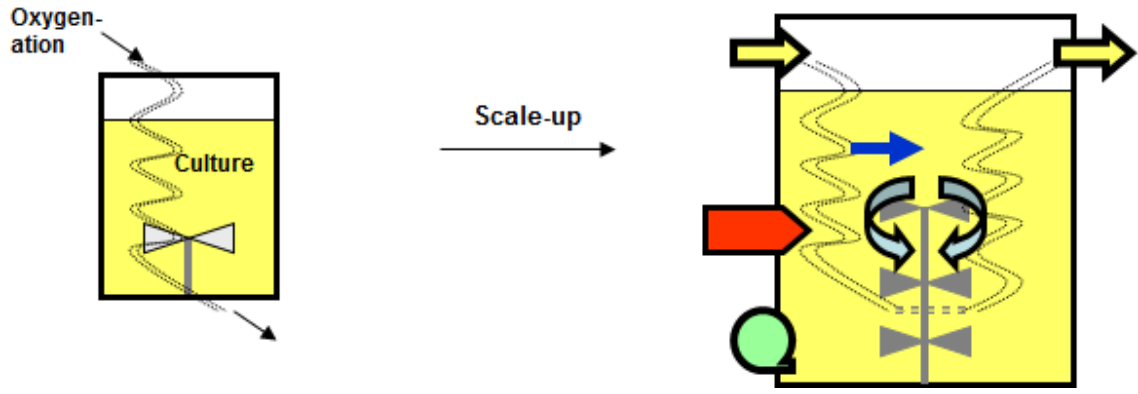


\section{B (cont)}

(iv)
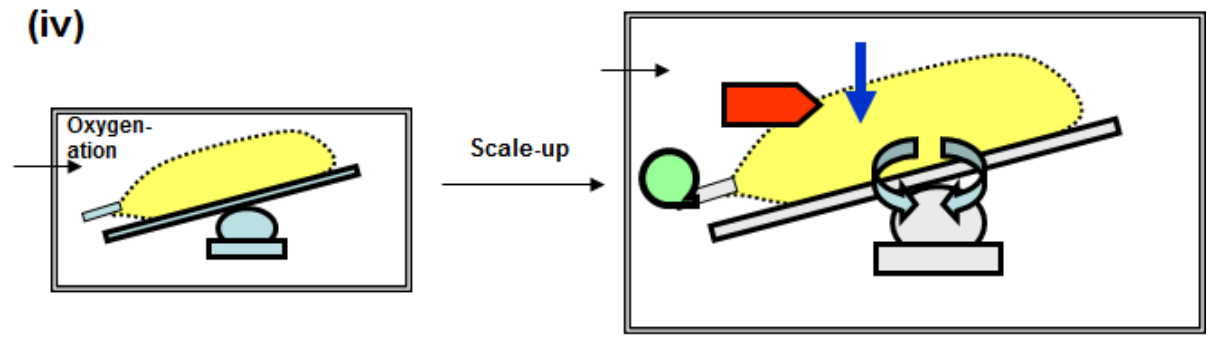

(v)
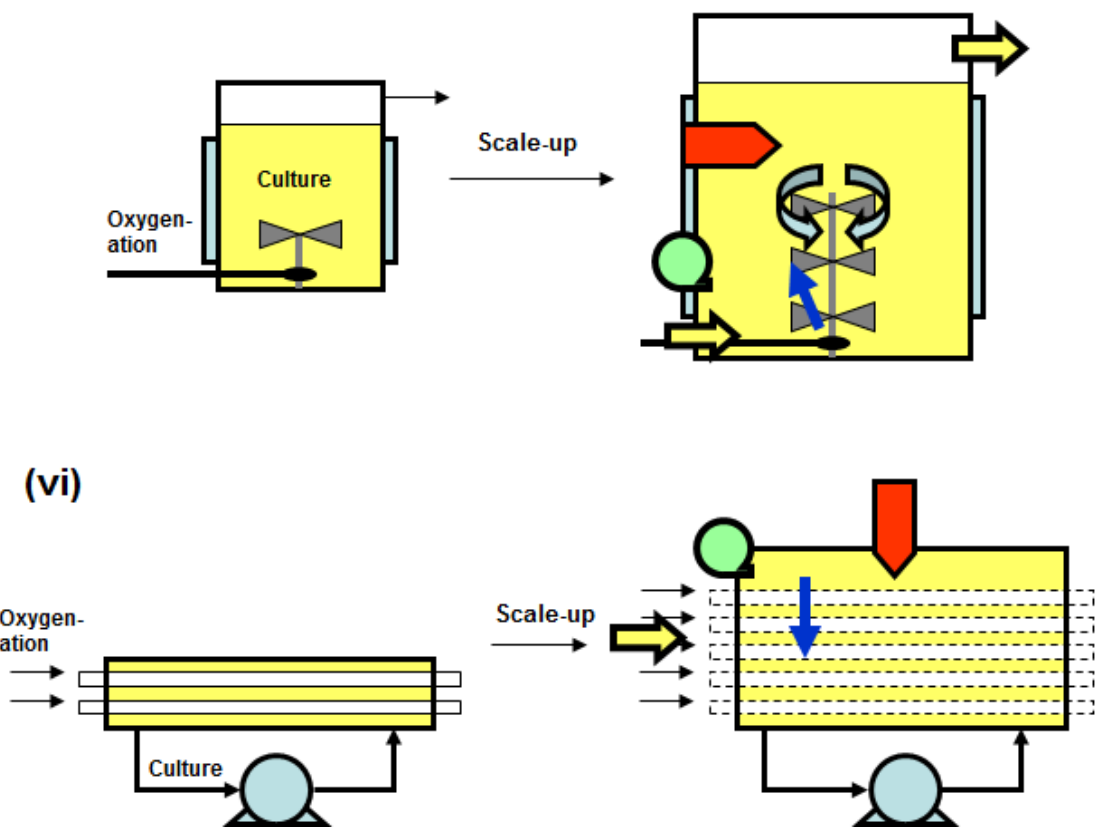

Figure 6

Functions and sub-functions interaction matrices (FIM) of the systems of a bioreactor to be scaled-up: A functions interaction matrix for all of the systems in the scaled-up bioreactor (A). The same matrix zoomed in on the technical system functions $(B)$, and on the biological system functions $(C)$.

In combination with the Hubka-Eder map all functions and subfunctions that have major impacts in the FIM are consider in a systematic approach to generate conceptual design solutions. In the concept generation chart the basic concept 
components are identified which then are permuted into concept alternatives (Figure 7). First, the basic functions are depicted with symbols without suggesting any configuration or construction objects (Figure 7A).

In the example of scale-up of cells producing a recombinant protein these basic components are evident: The cell culture must in some way be contained, agitated, supplied with nutrients and gas that are transported. Heat as well as a gas separator of some kind is most probably needed. These basic components are derived from the Hubka-Eder map. The basic concept components are possible to combine in a variety of configurations which later will be converted to anatomical objects. The basic conceptual component of the cell culture bioreactor can, of course, also be identified from existing bioreactor designs. However, the purpose of the systematic design is not to copy existing solutions, but to generalize the concepts and to generate new and better solutions for reaching the target specifications.

In Figure 7B six concept alternatives are configured by permutation of the basic components. With the available basic components several other configurations can, of course, easily be created. Also, some components can be used repeatedly, thereby forming additional alternatives (e.g. alternatives ii and $v i$ where the containment components are multiplied).

As mentioned, the FIM analysis directs the attention of the concept generation to permutation solutions that have impact on the major interactions in the FIM. For example, the gas-liquid interface is in focus in all six concepts where the agitation and blending methods are varied considerably since these, according to the FIM, are decisive for the efficiency of the design and their effect on the scale-up. In a suspension culture of e.g. recombinant $\mathrm{CHO}$ - or hybridoma cells this effect is critical. 

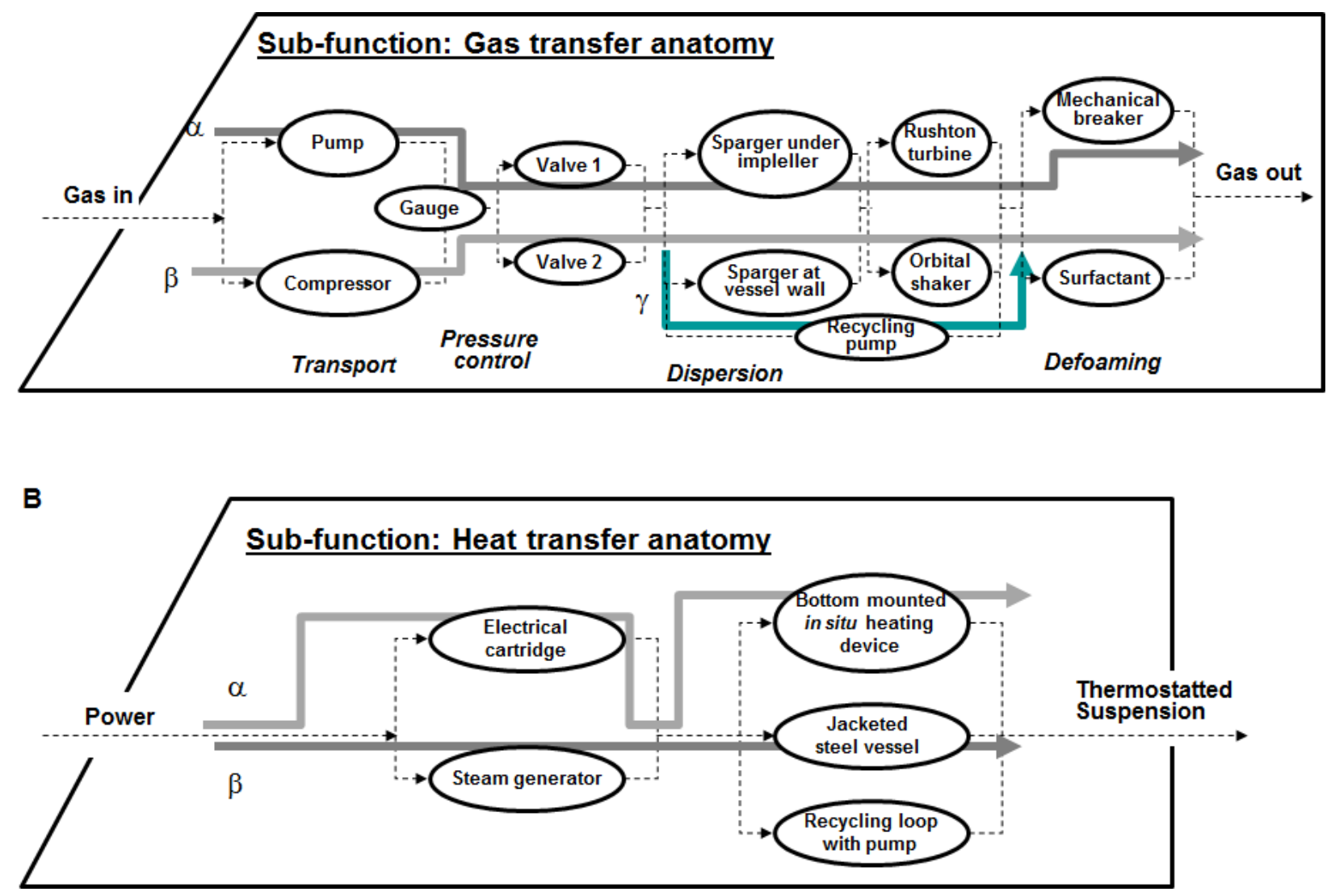

C

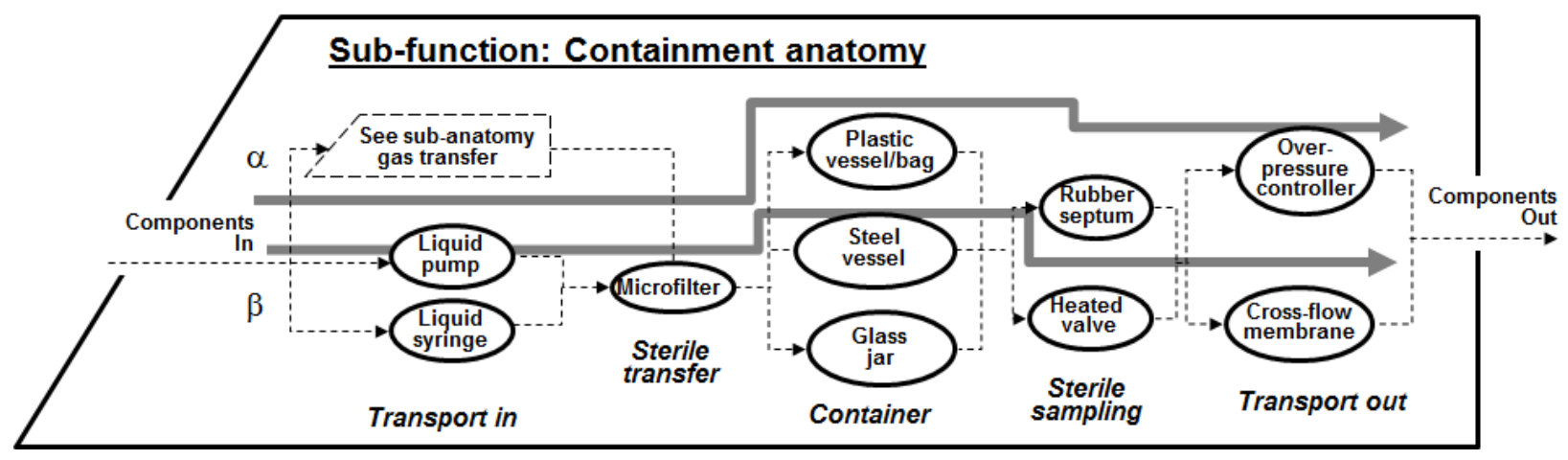

Figure 7

The basic functional components of a bioreactor for a cell culture where nutrients are converted to new cells and extracellular products $(A)$. Permutation of these components into six conceptual scale-up alternatives (B); permutations $\mathrm{i}$, iii and $\mathrm{v}$ show concepts based on a stirred tank; permutation ii and vi concepts with multilayer reactors, and concept iv a bioreactor where the whole container is kept in motion. 
Heat transfer functions have in the FIM analysis been graded with minor interactions. Thus, the Figure 7B alternatives show lesser concern to this and rely on external heat transfer. In a typical hybridoma culture cooling and heating are easily achieved with a jacket around the container which all the concepts could be provided with, whereas a microbial culture would be significantly more sensitive, especially to the cooling capacity in concepts ii, iv and vi.

The assumed shear sensitivity of mammalian cells is probably of lesser concern in concept $i$, iii and $v$, assuming lower impeller speed when scaled-up.

The six concept alternatives are coarsely screened towards the scale-up need attributes listed in Table 1 and 2 . The screening is graded at three levels $(-, 0,+)$. The sum of the assessed scores for the needs results in a ranking value for each alternative. The bottom row in the matrix shows the rank where 1 is the most favourable alternatives (Table 3).

The sum of the scores is highest and the same for alternatives iii, $v$ and $v i$ although due to different attribute scoring. Thus, concept $v$ scored positive in energy dissipation due to the better distribution of gas and heat, a higher $k_{L} a$, low variation in energy dissipation as an effect of better agitation and better productivity, and allowing a higher scale-up factor in comparison to the other alternatives. On the other hand, cell lysis could in this reactor configuration be significant and power consumption higher which render negative scores. Concept $v i$ has similar scoring although $k_{\llcorner} a$ and the scale-up factor are less favourable.

Since alternative iii, $v$ and $v i$ scored highest these were selected for further development. As seen in Figure 7B, these concepts relate to a configuration where oxygenation is carried out through a membrane immersed in a wide container with internal agitation (iii), a configuration where oxygen is transferred to the liquid via a gas inlet and by agitation ( $v$ ), and a third configuration where gas permeable tubes traverse the container and the medium is recycled $(v i)$. 
The three concepts are configured with physical, chemical or biological objects in anatomical charts. Figure 8 shows how this is done for the subfunctions gas transfer, heat transfer and containment. Normally, these objects or devices are commercially available but could also be developed as prototypes. The charts include several alternative devices which, by that, introduce alternative pathways.

The gas transfer subfunction involves objects for gas transport, pressure control, dispersion of gas in the medium and defoaming (Fig. 8A). Gas transport can be carried out by pumps or compressors. Gas dispersion can be carried out by gas transfer from the headspace of the vessel or by spargers. Defoaming is done by mechanical foam breaking or by addition of antifoam agents (note that an antifoam chemical is here also considered an object).

The heat transfer subfunction has several anatomical solutions (Fig. 8B). The heat can be transferred electrically by a heat cartridge, by cooling water or heating steam, or by carrying out the operation in a thermostatted cabinet. The heat transfer can take place in situ or by using a jacket or by recycling the medium. Heat transfer equations describing the capacities of the different anatomical configurations can support the evaluation.

The containment subfunction (Fig. 8C) involves, except the container objects (here, a single use plastic device, a steel vessel and a glass jar), objects for sterile transfer (a micro-filter), for sterile sampling (septum, heated valve), and transport out.

Alternative pathways of objects in the anatomical charts are compared in a new screening matrix. The scorings in the matrix rank the anatomical alternatives and indicates favourable alternatives. Table 4 shows the matrix for the three anatomical configurations in Figure 8 considering the different pathways of objects where the three concepts are compared versus subfunctions, anatomical pathways and user attributes. In the gas transfer subfunction a third pathway $\gamma$ is added. The cost attribute has been divided in equipment cost and cost for development work. The scoring is at four levels: very favourable, good, modest, or insignificant or irrelevant. The scoring is not based on experimental tests at 
this stage but on experiences and theoretical reasoning. For most of the scores this is uncomplicated.

The sum of scores (right column) indicates the preferred configurations. As the table shows, it is the $v$ concept that comes out as the best for all configurations: for gassing it is the pathway $\alpha$ with score 22 , for heating pathway $\beta$ with 20 , and for containment pathway $\alpha$ with 24 . Thus, in the anatomical subfigures in Figure 8 the grey lines depict the preferred anatomies. Consequently, these should be chosen with e.g. a plastic container, gas transfer by sparging, and heating by steam which all has highest scores. Thus, this conceptual anatomy is chosen for further development and prototyping when scaling-up a hybridoma or recombinant cell culture process.

\section{Concluding remarks}

The biomechatronic design methodology provides bioreactor scale-up with an additional tool for structuring process development. The mathematical engineering framework is already at hand for the analytical description of important events during scale-up, such as mass and heat transfer in the agitated and aerated bioreactor environment.

By integrating the existing engineering framework with the biomechatronic design methodology an easily overviewed structure and a sequential working procedure are suggested for comprehensively dealing with the entire scale-up development work.

This may be of particular value for new emerging technology such as stem cell manufacturing, where the cellular transformation process is quite different from traditional bioprocesses, and where scale-up principles are at present not founded [6, 39].

The realization of Quality-by-Design concepts in the pharmaceutical industry is another example of novel design needs where a design methodology can play a role during the scale-up of the (bio)-pharmaceutical manufacturing process [21]. 
The integration of mathematical tools in the design is therefore of particular interest in order to facilitate the work, for example using statistical approaches, design-of-experiments [40] and mechanistic modelling [41, 42].

Also, access to new information systems for scale-up could improve the efficiency of the scale-up work process. Such systems exemplify the $\Sigma / S$ of the Hubka-Eder map. Furthermore, the $\Sigma / S$ link very directly to the purpose and intentions of Process Analytical Technology (PAT) [36].

Taken together, the biomechatronic methodology enhances speed-up and accuracy during scale-up process R\&D. By that, it is actually also related to GMP and to Quality Assurance as well. 


\section{References}

[1] Godoy-Silva, R., Berdugo, C., Chalmers, J.J., Aeration, mixing, and hydrodynamics, animal cell bioreactors. In: Encyclopedia of Industrial Biotechnology (ed. by Flickinger, M.C.) 2010, 1, 87-113.

[2] Nienow, A. W., Reactor engineering in large scale animal cell culture. Cytotechnology 2006, 50, 9-33.

[3] Griffiths, J. B., Mammalian cell culture reactors, scale-up. In: Encyclopedia of Industrial Biotechnology (ed. by Flickinger, M.C.) 2010, 5, 3228-3241.

[4] Zhang, H., Wang, W., Quan, C., Fan, S., Engineering considerations for process development in mammalian cell cultivation. Current Pharmaceutical Biotechnol. 2010, 11, 103-112.

[5] Shukla, A.A., Thoemmes, J., Recent advances in large-scale production of monoclonal antibodies and related proteins. Trend Biotechnol2010, 28, 253-261.

[6] Jensen, J., Hyllner, J., Björquist, P., Human embryonic stem cell technologies and drug discovery. J. Cell. Physiol. 2009, 219, 513-519.

[7] Schmelzer, E., Triolo, F., Turner, M.E., Thompson, R.L., Zeilinger, K., Reid, L.M., Gridelli, B., Gerlach, J.C., Three-dimensional perfusion bioreactor culture supports differentiation of human fetal liver cells. Tissue Eng. Part $A$ 2010, 16, 2007-2016.

[8] Godara, P., McFarland, C.D., Nordon, R.E., Design of bioreactors for mesenchymal stem cell tissue engineering. J. Chem. Technol. Biotechnol. 2008, 83, 408-420.

[9] Thomas, R.J., Anderson, D., Chandra, A., Smith, N.M., Young, L.E., Williams, D., Denning, C., Automated, scalable culture of human embryonic stem cells in feeder-free conditions. Biotechnol. Bioeng. 2009, 102, 16361644. 
[10] Nauman, B., Handbook of chemical reactor design, optimization and scaleup, McGraw-Hill, New York, 2001.

[11] Marks, D.M., Equipment design considerations for large scale cell culture. Cytotechnology 2003, 42, 21-33.

[12] Langheinrich, C., Nienow, A.W., Control of $\mathrm{pH}$ in large-scale, free suspension animal cell bioreactors: alkali addition and $\mathrm{pH}$ excursions. Biotechnol. Bioeng. 1999, 66, 171-179.

[13] McCabe, W.L., Smith, J., Harriot, P., Unit operations of chemical engineering (7th edition), McGraw-Hill, New York, $2005 .$.

[14] Ullman, D.G., The mechanical design process, $3^{\text {rd }}$ edition, McGraw-Hill, New York, 2003.

[15] Pahl, G., Beitz, W. Engineering design, a systematic approach, Springer Verlag, Berlin, 1996.

[16] Roozenburg, N.F.M., Eekels, J., Product design: fundamentals and methods, John Wiley \& Sons, Chichester, 1996.

[17] Ulrich, K.T., Eppinger, S.D., Product Design and Development, 3rd edition, McGraw-Hill, New York, 2007.

[18] Mandenius, C.F., Björkman, M., Design principles for biotechnology product development. Trend. Biotechnol. 2010, 28, 230-236.

[19] Mandenius, C.F., Björkman, M., Biomechatronic design in biotechnology: a methodology for development of biotechnological products, John Wiley \& Sons Inc, Hoboken, New Jersey, 2011

[20] Derelöv, M., Detterfelt, J., Björkman, M., Mandenius, C.F., Engineering design methodology for bio-mechatronic products. Biotechnol. Prog. 2008, 24, 232-244.

[21] Mandenius, C.F., Björkman, M., Process analytical technology (PAT) and Quality-by-Design $(\mathrm{QbD})$ aspects on stem cell manufacture. Eur. Pharm. Rev. 2009, 14, 32-37. 
[22] Mandenius, C.F., Derelöv, M., Detterfelt, J., Björkman, M., Process analytical technology and design science. Eur. Pharm. Rev. 2007, 12, 74-80.

[23] Hubka, V., Eder, W.E., Theory of technical systems, a total concept theory for engineering design, Springer Verlag, Berlin, 1988.

[24] Hubka, V., Eder, W.E., Engineering design, general procedural model of engineering design, Heurista, Zürich, 1992.

[25] Hubka, V., Eder, W.E., Design science, Springer Verlag, Berlin. 1996.

[26] Neubauer P., Towards faster bioprocess development. Biotechnol. J. 2011, 6, 902-903.

[27] Noorman, H., An industrial perspective on bioreactor scale-down: What can we learn from combined large-scale bioprocess and model fluid studies. Biotechnol. J. 2011, 6, 934-943.

[28] Schweder, T., Bioprocess monitoring by marker gene analysis. Biotechnol J. 2011, 6, 926-933.

[29] Atkinson, B., Manituva, F., Biochemical engineering and biotechnology handbook. $2^{\text {nd }}$ ed., Stockton Press, New York, 1991.

[30] Cho M.H., Wang S.S., Enhancement of oxygen transfer in Hybridoma cell culture by using a perfluorocarbon as an oxygen carrier. Biotechnol. Lett. 2005, 10, 855-860.

[31] Pörtner, R., Schäfer T., Modelling hybridoma cell growth and metabolism--a comparison of selected models and data. J. Biotechnol. 1996, 49, 119-135.

[32] Bibila, T.A., Flickinger M.C., Use of a structured kinetic model of antibody synthesis and secretion for optimization of antibody production systems: I. Steady-state analysis. Biotechnol. Bioeng. 1992, 39, 251-261.

[33] Nienow, A.W., Langheinrich, C., Stevenson, N.C., Emery, A.N., Clayton, T.M., Slater, N.K.H., Homogenisation and oxygen transfer rates in large agitated and sparged animal cell bioreactors: some implications for growth and production. Cytotechnology 1996, 22, 87-94. 
[34] Langheinrich C, Nienow AW, Eddleston T, Stevenson NC, Emery AN, Clayton TM, Slater NKH (2002) Oxygen transfer in stirred bioreactors under animal cell culture conditions. Food Bioproduct Proc (Trans I Chem E, Part C) $80: 39-44$

[35] Van't Riet K, Tramper J (1991) Basic bioreactor design. Marcel Dekker, N.Y

[36] Glassey, J., Gernaey, K.V., Oliveria, R., Striedner, G., Clemens, C., Schultz, T.V., Mandenius, C.F., PAT for biopharmaceuticals. Biotechnol. J. 2011, 6, 369-377.

[37] Mandenius, C.F., Recent developments in monitoring, modelling and control of biological production systems. Bioproc Biosys Eng 2004, 26, 347-351.

[38] Mandenius C-F, Graumann K, Schultz TW, Premsteller A, Olsson I-M, Periot E, Clemens C, Welin M. 2009. Quality-by-Design (QbD) for biotechnology-related phamaceuticals. Biotechnol. J. 4, 11-20.

[39] Mandenius, C.F., Andersson, T.B., Alves, P.M., Batzl-Hartmann C, Björquist P, Carrondo MJT, Chesne C, Coecke S, Edsbagge J, Fredriksson JM, Gerlach JC, Heinzle E, Ingelman-Sundberg M, Johansson I, KüppersMunther B, Müller-Vieira U, Noor F, Zeilinger K., Towards preclinical predictive drug testing for metabolism and hepatotoxicity by in vitro models derived from human embryonic stem cells: a report on the Vitrocellomics EU-project. Altern. Lab. Anim. (ATLA) 2011, 39, 147-171.

[40] Mandenius, C.F., Brundin A., Bioprocess optimization using design-ofexperiments methodology (DoE). Biotechnol. Prog. 2008, 24, 1191-1203.

[41] Hutmacher, D.W., Singh, H., Computational fluid dynamics for improved bioreactor design and 3D culture. Trend. Biotechnol. 2008, 26, 166-172.

[42] Gernaey, K.V., Lantz, A.E., Tufvesson, P., Woodley, J.M., Sin, G., Application of mechanistic models to fermentation and biocatalysis for nextgeneration processes. Trends Biotechnol. 2010, 28, 346-354. 


\section{Table 1 User needs on the scaled-up cell culture bioreactor}

\begin{tabular}{ll}
\hline User need & Bioengineering Property \\
\hline $\begin{array}{l}\text { The scale-up should not result in a cell } \\
\text { suspension with gradients }\end{array}$ & Homogeneous reactor \\
$\begin{array}{l}\text { The volumetric transfer of heat should be } \\
\text { unaffected of scale-up }\end{array}$ & Heat transfer efficiency \\
$\begin{array}{l}\text { The scale-up should not reduce mass transfer of } \\
\text { media constituents }\end{array}$ & Mass transfer efficiency \\
$\begin{array}{l}\text { The cells should not be harmed due to aeration } \\
\text { or agitation }\end{array}$ & Shear stress \\
$\begin{array}{l}\text { The scale up should not reduce the growth rate } \\
\text { of the culture }\end{array}$ & Specific cell growth \\
$\begin{array}{l}\text { Cells should not be damage by large scale } \\
\text { impellers }\end{array}$ & Bioreactor rheology \\
$k_{L}$ a should be sufficient for maximal growth & Oxygen transfer efficiency \\
$\begin{array}{l}\text { The volumetric productivity of the culture should } \\
\text { be unaffected }\end{array}$ & Productivity of expressed protein \\
Nutrient yield shall be unaffected by the scale-up & Yield factors
\end{tabular}




\section{Table 2 Target specifications for the scaled-up cell culture bioreactor}

\begin{tabular}{lcc}
\hline Attribute & Unit & Metrics \\
\hline Cell density & cells mL & $10^{-1}-10^{7}$ \\
Agitation power & $\mathrm{W} \mathrm{m}^{-3}$ & $1-2$ \\
Mean specific energy dissipation rate & $\mathrm{W} \mathrm{kg}^{-1}$ & $0.01-0.25$ \\
$k_{\mathrm{L} a}$ & $\mathrm{~h}^{-1}$ & $1-15$ \\
Variation in local specific energy & $\%$ & $<5$ \\
dissipation rate & \% lysis per day & $<4$ \\
Cell lysis & g product / g cell / h & $>0.01$ \\
Productivity gain & man-month & $36-48$ \\
Scale-up cost & volume/volume & $>100$ \\
Scale-up factor & & \\
\hline
\end{tabular}


Table 3 Assessment of conceptual scale-up alternatives

\begin{tabular}{|c|c|c|c|c|c|c|}
\hline User attributes & $\underset{i}{\text { Concept }}$ & $\begin{array}{c}\text { Concept } \\
\text { ii }\end{array}$ & $\begin{array}{c}\text { Concept } \\
\text { iii }\end{array}$ & $\begin{array}{c}\text { Concept } \\
\text { iv }\end{array}$ & $\begin{array}{c}\text { Concept } \\
\text { v }\end{array}$ & $\begin{array}{c}\text { Concept } \\
\text { vi }\end{array}$ \\
\hline Cell density & - & 0 & + & 0 & 0 & + \\
\hline Power & - & + & - & + & - & + \\
\hline $\begin{array}{l}\text { Mean specific } \\
\text { energy } \\
\text { dissipation rate }\end{array}$ & - & 0 & + & 0 & + & + \\
\hline$k_{L} a$ & - & - & 0 & - & + & - \\
\hline $\begin{array}{l}\text { Variation in local } \\
\text { specific energy } \\
\text { dissipation rate }\end{array}$ & - & - & - & - & + & 0 \\
\hline Cell lysis & - & + & + & + & - & + \\
\hline Productivity gain & 0 & 0 & + & + & + & + \\
\hline Scale-up cost & 0 & 0 & 0 & 0 & 0 & 0 \\
\hline Scale-up factor & + & 0 & + & 0 & + & - \\
\hline Sum & -5 & 0 & 3 & 1 & 3 & 3 \\
\hline Rank & 4 & 3 & 1 & 2 & 1 & 1 \\
\hline
\end{tabular}


Table 4 Assessment of anatomical alternatives

\begin{tabular}{|c|c|c|c|c|c|c|c|c|c|c|c|c|}
\hline \multirow[b]{2}{*}{ 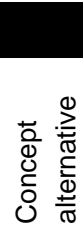 } & \multirow[b]{2}{*}{ 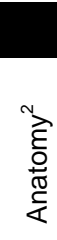 } & \multirow[b]{2}{*}{ 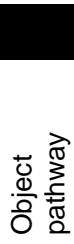 } & \multicolumn{9}{|c|}{ User attributes $^{1}$} & \multirow[b]{2}{*}{ Sum } \\
\hline & & & Cell density & Power & $k_{L} a$ & $\begin{array}{l}\text { Variation in local } \\
\text { specific energy } \\
\text { dissipation rate }\end{array}$ & Cell lysis & $\begin{array}{l}\text { Productivity } \\
\text { gain }\end{array}$ & $\begin{array}{l}\text { Scale-up } \\
\text { equipment } \\
\text { cost }\end{array}$ & $\begin{array}{c}\text { Scale-up } \\
\text { work cost }\end{array}$ & $\begin{array}{l}\text { Scale-up } \\
\text { factor }\end{array}$ & \\
\hline \multirow[t]{6}{*}{$\overline{\text { iii }}$} & \multirow{2}{*}{ ర্ } & $\alpha$ & ++ & ++ & ++ & +++ & ++ & ++ & ++ & ++ & ++ & 19 \\
\hline & & $\beta$ & + & ++ & +++ & +++ & +++ & +++ & ++ & ++ & ++ & 21 \\
\hline & \multirow{2}{*}{$\begin{array}{l}\mathbb{\pi} \\
\stackrel{\mathbb{\Phi}}{I}\end{array}$} & $\bar{\alpha}$ & +++ & $\overline{++}$ & 0 & ++ & + & ++ & $\overline{++}$ & $\overline{++}$ & + & 15 \\
\hline & & $\beta$ & +++ & + & 0 & +++ & ++ & ++ & ++ & ++ & ++ & 17 \\
\hline & \multirow{2}{*}{$\overrightarrow{0}$} & $\alpha$ & +++ & +++ & ++ & ++ & +++ & ++ & + & ++ & ++ & 20 \\
\hline & & $\beta$ & +++ & +++ & ++ & ++ & ++ & ++ & +++ & ++ & +++ & 22 \\
\hline \multirow[t]{6}{*}{ v } & \multirow{2}{*}{$\underset{\mathbb{N}}{\mathbb{0}}$} & $\alpha$ & +++ & +++ & +++ & +++ & + & +++ & + & ++ & +++ & 22 \\
\hline & & $\beta$ & +++ & + & + & + & +++ & ++ & + & ++ & +++ & 17 \\
\hline & \multirow{2}{*}{$\begin{array}{l}\ddot{\pi} \\
\stackrel{\mathbb{\pi}}{I}\end{array}$} & $\alpha$ & ++ & +++ & 0 & ++ & ++ & + & ++ & ++ & + & 15 \\
\hline & & $\beta$ & +++ & ++ & 0 & +++ & +++ & ++ & ++ & ++ & +++ & 20 \\
\hline & \multirow{2}{*}{ రั } & $\alpha$ & +++ & +++ & +++ & +++ & +++ & ++ & +++ & ++ & ++ & 24 \\
\hline & & $\beta$ & +++ & + & +++ & +++ & ++ & ++ & + & ++ & +++ & 20 \\
\hline \multirow[t]{6}{*}{$\mathrm{vi}$} & \multirow{2}{*}{$\underset{\mathbb{E}}{\mathbb{0}}$} & $\alpha / \gamma$ & + & +++ & + & + & $\overline{++}$ & + & + & + & + & 12 \\
\hline & & $\beta / \gamma$ & + & +++ & + & + & +++ & + & + & + & + & 13 \\
\hline & \multirow{2}{*}{$\begin{array}{l}\mathbb{\infty} \\
\stackrel{\mathbb{1}}{1}\end{array}$} & $\alpha$ & ++ & +++ & 0 & + & + & + & + & + & ++ & 12 \\
\hline & & $\beta$ & +++ & ++ & 0 & ++ & ++ & ++ & + & + & + & 14 \\
\hline & \multirow{2}{*}{ 풍 } & $\alpha$ & ++ & +++ & + & ++ & ++ & ++ & + & + & + & 15 \\
\hline & & $\beta$ & ++ & +++ & + & ++ & + & ++ & + & + & + & 14 \\
\hline
\end{tabular}

1) Scoring: +++ , very favourable; ++ , good; + modest; 0 , no influence or irrelevant

2) Gas = gas transfer anatomy; Heat $=$ heat transfer anatomy; Cont. = containment anatomy 


\section{Figure legends}

\section{Figure 8}

Anatomical charts showing structures of three of the subfunctions of the technical system(s): (A) The gas transfer subfunction with anatomical objects for supplying gas to the reactor, $(B)$ the heat transfer subfunction with objects for heating and cooling of the bioreactor, and $(C)$ the subfunction for containment of the bioreactor with vessels and ports for gas, liquid and sample withdrawal. 
